\title{
The Chosen Aspects of Urbanization in Poland
}

\section{Rajmund S. MYDEL*}

The rapid growth in urban population both in absolute figures and in its share of the total population is very significant in many countries in the world. This growth is also observed in Poland (Tab. 1), where at the turn of the 19th and 20th centuries the share of urban population was $27 \%$ and reached $37 \%$ prior to the Second World War. The intensive development of the Polish economy, especially industry, after the Second World War caused rapid urbanization. The first post-war census of 1946 revealed that approximately $35 \%$ of the population lived in urban areas, although $50 \sim 80 \%$ of the buildings in those areas were destroyed during the war. Towards the end of 1966 the proportion of urban and rural population was in equilibrium. The most recent census data (1980) indicates that $58.7 \%$ of the total population lived in towns and cities. This means that Poland is one of the more urbanized countries in Europe(i. e. Norway 44.2 $\%$, Austria 51.9\%, Hungary $53.1 \%$, and Spain 55. 4\%).

Table 1 Historical changes in the population of Poland*

\begin{tabular}{rrrc}
\hline Year & \multicolumn{1}{c}{ Total } & Cities & $\begin{array}{c}\text { Urban } \\
\text { population } \\
\text { (millions) }\end{array}$ \\
\hline 1810 & 9.0 & 2.0 & 22.2 \\
1850 & 14.0 & 3.1 & 22.2 \\
1900 & 23.7 & 6.3 & 26.6 \\
1910 & 28.6 & 8.1 & 28.3 \\
1939 & 32.5 & 12.0 & 36.9 \\
1946 & 23.6 & 8.0 & 34.0 \\
1950 & 25.0 & 9.6 & 38.4 \\
1960 & 29.8 & 14.4 & 48.3 \\
1970 & 32.7 & 17.1 & 52.3 \\
1980 & 35.6 & 21.0 & 58.7 \\
\hline
\end{tabular}

* on present-day territory of country
The growth of the share of the urban population in the total population of Poland was caused by natural increase, influx of rural population to towns and administrative changes. In the course of the 30 years between 1950 and 1980, the Polish urban population increased by 11.4 million $(54.3 \%)$. Exactly $42.4 \%$ of this figure is due to natural increase, $33.9 \%$ to migrations from rural areas and $23.7 \%$ to administrative changes. The proportions of these factors in the total urban population growth were very different in the post-war urbanization history of Poland. For example in the period from 1951 1955, 40.6\% of the growth of the total urban population was caused by the introduction of the new administrative division and administrative reorganization of the settlement system of the country(Fig. 1). In the period from $1976 \sim 1980$ the share of the administrative changes in the total growth of the urban population was only $9.6 \%$. The most important factors in the growth of the urban population in this period were migrations (46. $1 \%$ ) and natural increase (44. 3\%).

At the end of 1980 Poland had 804 towns and cities (Tab. 2). Since 1950 the number of towns and urban settlements has increased by 98 . Simultaneously in the period 1950 1980 urban settlements with a population of below 5,000 inhabitants have decreased by 129. The proportion of these urban settlements in the total urban population has decreased from $11.1 \%$ to $3.8 \%$. In this category of urban settlements numerous cases of stagnation and decrease in population are observed, due to the complete absence of industry and very slow development of the service and trade sector of their economy. Cases of stagnation and decrease

\footnotetext{
* Department of Geography, Jagiellonian University, Polish People's Republic.
} 


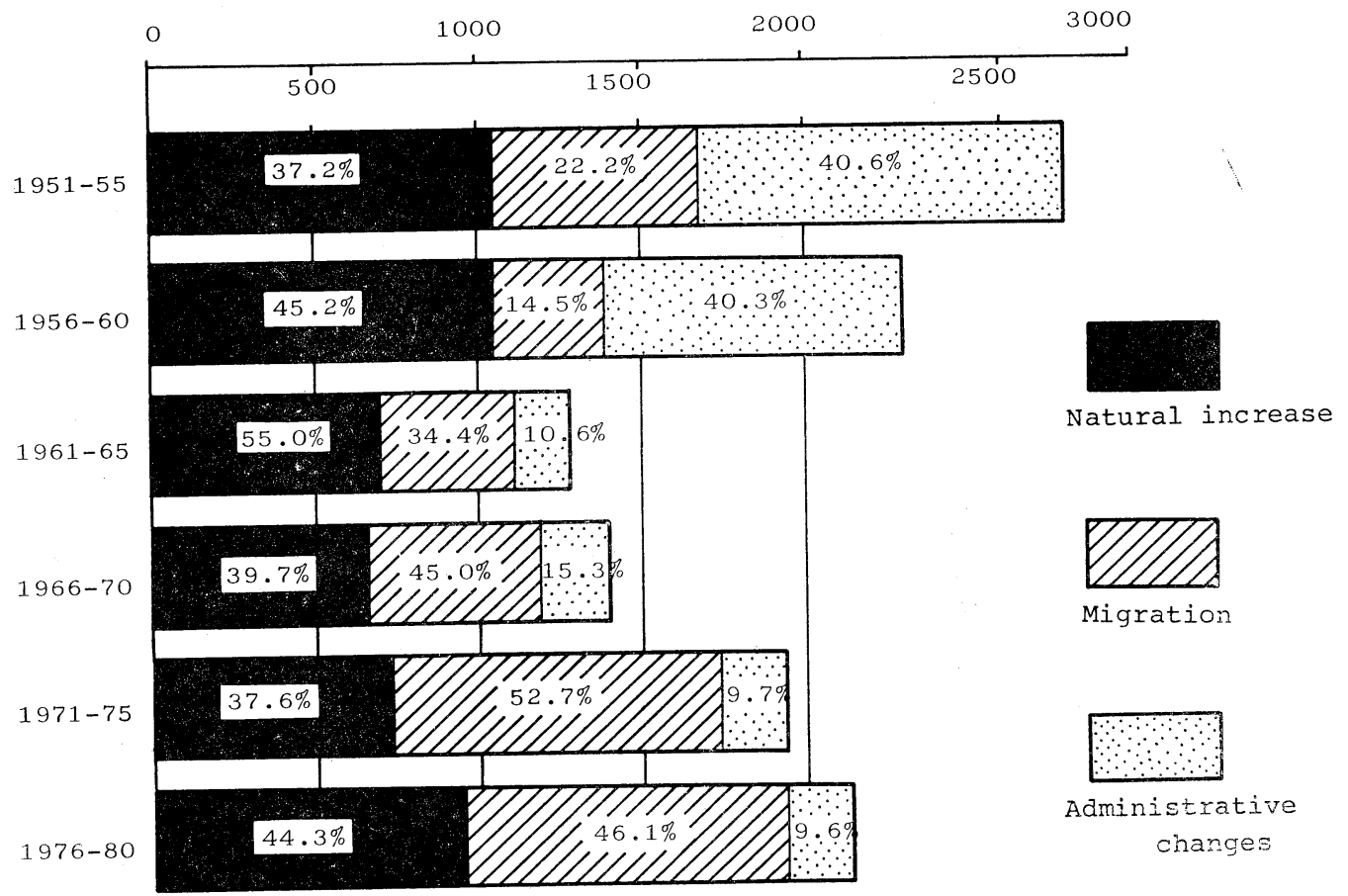

Figure 1. Factors of the urban population increase in Poland

Table 2 Number of Polish cities by population size categories in 1950 and 1980

\begin{tabular}{|c|c|c|c|c|c|c|c|c|}
\hline \multirow[b]{2}{*}{$\begin{array}{l}\text { Size of cities } \\
\left(\begin{array}{l}\text { thousands } \\
\text { inhabitants }\end{array}\right)\end{array}$} & \multicolumn{4}{|c|}{1950} & \multicolumn{4}{|c|}{1980} \\
\hline & $\begin{array}{c}\text { Number } \\
\text { of } \\
\text { cities }\end{array}$ & (\%) & $\begin{array}{c}\text { Number } \\
\text { of } \\
\text { population } \\
\text { (thousands) }\end{array}$ & (\%) & $\begin{array}{l}\text { Number } \\
\text { of } \\
\text { cities }\end{array}$ & $(\%)$ & $\begin{array}{c}\text { Number } \\
\text { of } \\
\text { population } \\
\text { (thousands) }\end{array}$ & (\%) \\
\hline below 5 & 393 & 55.7 & 1,066 & 11.1 & 264 & 32.8 & 787 & 3.8 \\
\hline $5-10$ & 159 & 22.5 & 1,114 & 11.6 & 185 & 23.1 & 1,283 & 6.1 \\
\hline $10-20$ & 76 & 10.8 & 1,033 & 10.8 & 169 & 21.0 & 2,392 & 11.4 \\
\hline $20-50$ & 50 & 7.1 & 1,523 & 15.9 & 111 & 13.8 & 3,466 & 16.5 \\
\hline $50-100$ & 12 & 1.7 & 832 & 8.6 & 38 & 4.7 & 2,614 & 12.5 \\
\hline $100-200$ & 11 & 1.5 & 1,640 & 17.1 & 22 & 2.7 & 3,090 & 14.7 \\
\hline 200 and above & 5 & 0.7 & 2,397 & 24.9 & 15 & 1.9 & 7,347 & 35.0 \\
\hline Total & 706 & 100.0 & 9,605 & 100.0 & 804 & 100.0 & 20,979 & 100.0 \\
\hline
\end{tabular}

elaborated by the author

in population observed in a number of small towns are referred to as a "crisis of the small towns".

In contrast to the small towns, the medium sized and big cities developed dynamically after the war. In particular there has been a growth of cities with a population of more than 50,000 , the number of which in the period from 1950 1980 has increased from $28(3.9 \%$ of the total number of towns) to $75(9.3 \%)$. This means that $62.2 \%$ of the country's urban population is con- 


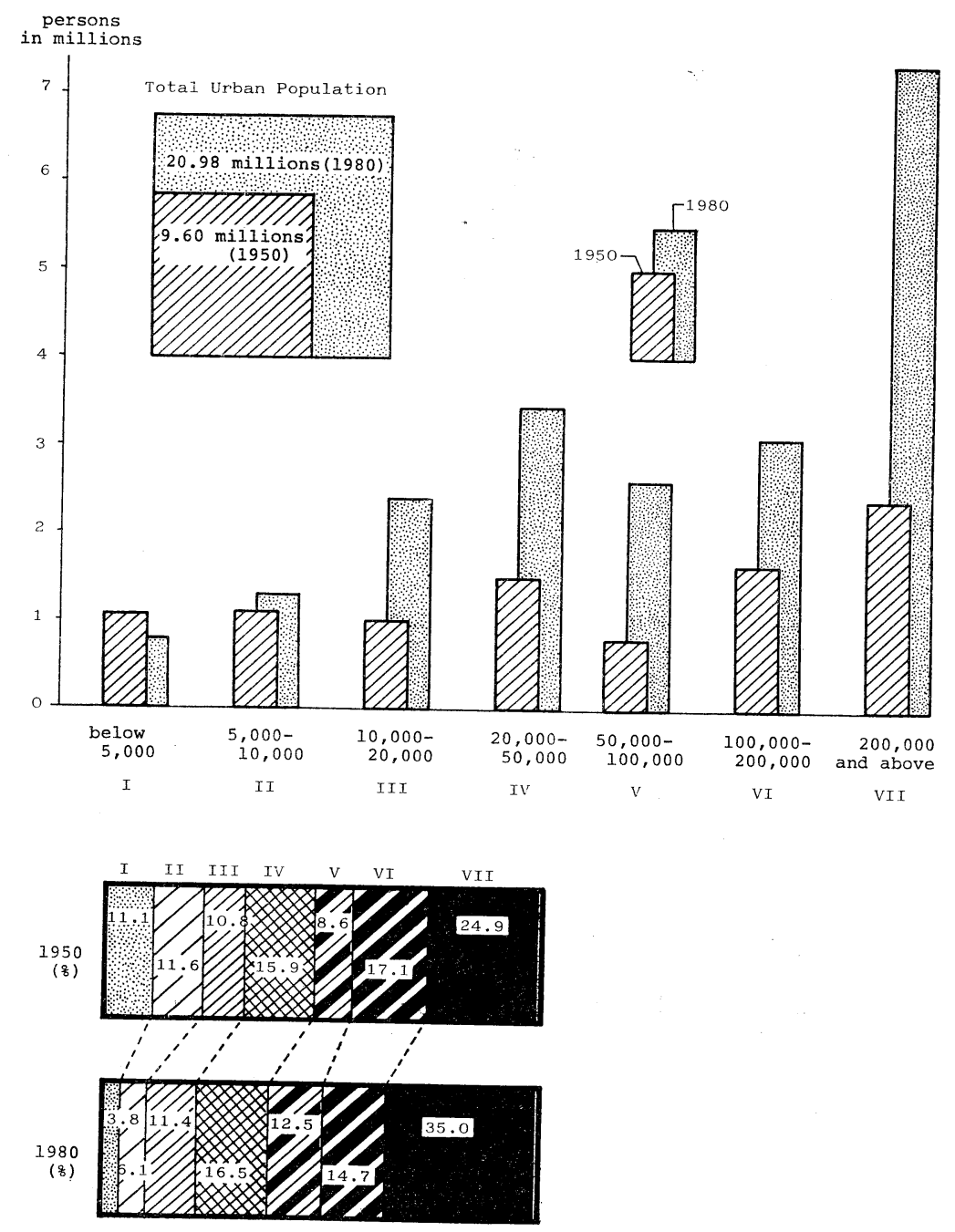

Figure 2. Polish towns by population size categories in 1950 and 1980

centrated in the medium and large sized cities. The data in Tab. 2 indicates, as in other countries, that the advance of urbanization in Poland is mainly due to the development of large and medium-sized cities, in which are concentrated most industrial investments and administrative, cultural, and trade-service institutions. These factors are responsible for the attraction of migrants from the rural areas and small urban settlements to the cities, who hope to find new jobs and opportunities to improve their financial and social positions.

From the spatial point of view the most urbanized regions are western and southerncentral Poland, which exceed the national average of urban population (58.7\%) (Fig. 3 ). The high level of urbanization in the western regions has a long historical basis, where during the period of Prussian annexation for about 200 years formed a fine net of urban settlements and towns. In the southern and central regions, the main factors of urbanization had been the intensive processes of industrialization, determined most often by existence and utilization of local raw materials such as hard coal, brown coal, iron, zinc, and lead ores. In- 


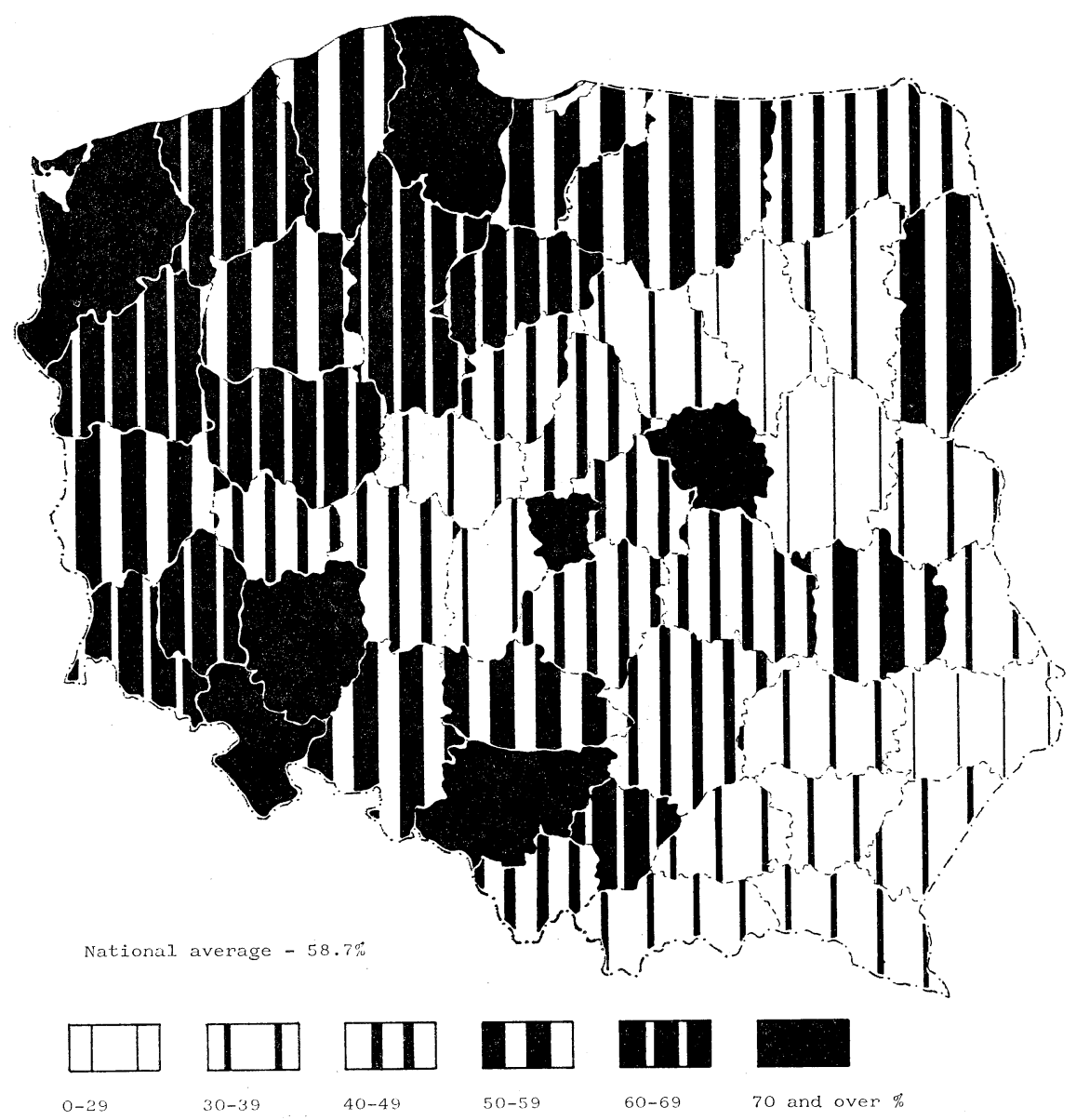

Figure 3. Share of urban population in the total population by voivodships(1980) in Poland

dustrialization represents the most important factor in the post-war history of Polish urbanization.

There were sixteen urban agglomerations in the country, which occupied about $10 \%$ of the territory in 1980 and had a concentration of about 13 million people. This means that urban agglomerations account for $22.1 \%$ of the total population and over $60 \%$ of the urban population of the country. Besides this they account for about 65\% of the employees in the country's industry. Now let us take Cracow's agglomeration which has a population of about 1 million as an example of detailed employment structure within Polish agglomeration. In this urban agglomeration about $40 \%$ of the total employees have been in industry, about
$20 \%$ in construction, $8 \%$ in transportation, $9 \%$ in trade, $11 \%$ in education, science, and culture, and the remaining $12 \%$ being in other sectors of the economy.

Out of 16 urban agglomerations (Fig. 5), 9 are fully developed: Upper Silesian conurbation (Upper Silesian Industrial Region with Katowice City as the main urban center); Cracow's agglomeration (together with Upper Silesian it becomes a core of the intensively urbanized and industrialized region of southern Poland); Warsaw agglomeration (as a capital of the country it has a special character); Łódź (rapidly developed, due to the textile industry development); Gdańsk-Gdynia and Bydgoszcz-Torun (interesting examples of bipolar agglomerations with very different economic structures); 


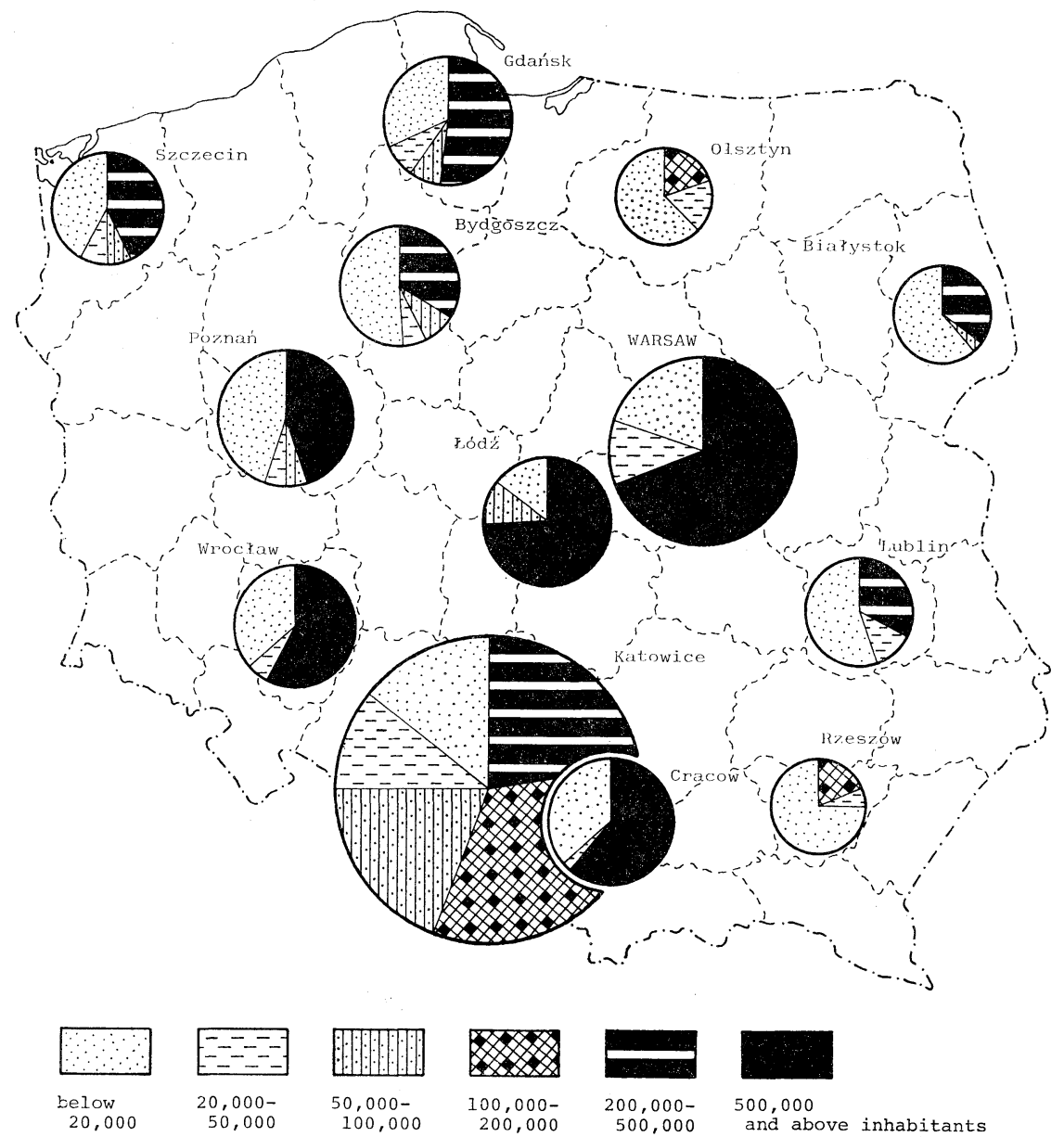

Figure 4. Urban population of chosen voivodships by size of cities(1980) in Poland The areas of circles are proportional to the number of urban population.

Wrocław, Pozńań, Szczecin agglomerations, which represent typical examples of monocentric agglomerations, strongly dominate the surroundings like Cracow's agglomeration.

Out of the 16 Polish urban agglomerations seven are partly developed: These are Sudets, Old Polish, Bielsko-Biała, Opole, Częstochowa, Lublin and Białystok all having urban centres with population less than 200, 000 inhabitants. Four emerging agglomerations (industrial conurbations) are also distinguished: the triangle with the main idustrial cities of Tarnobrzeg, Stalowa Wola, Sandomierz at the confluence of the Wisła and San rivers; the Sub-Carpathian with the agglomeration core in the cities of Rzeszów, Dębic and Tarnów; the Lower Silesian with the core of Lubin and Glogów towns ; and the Kalisz-Ostrów agglomeraion.

The dynamic progress of urbanization leads to fundamental changes in the population structure of urban settlements in terms of the natural increase and socio-occupational structure of the population.

In the period from 1950 1955 the natural increase in towns and cities was greater than in the rural areas due to the large scale immigration of young people and newly married couples to towns and cities (i. e. 19.2 per thousand in the urban areas 


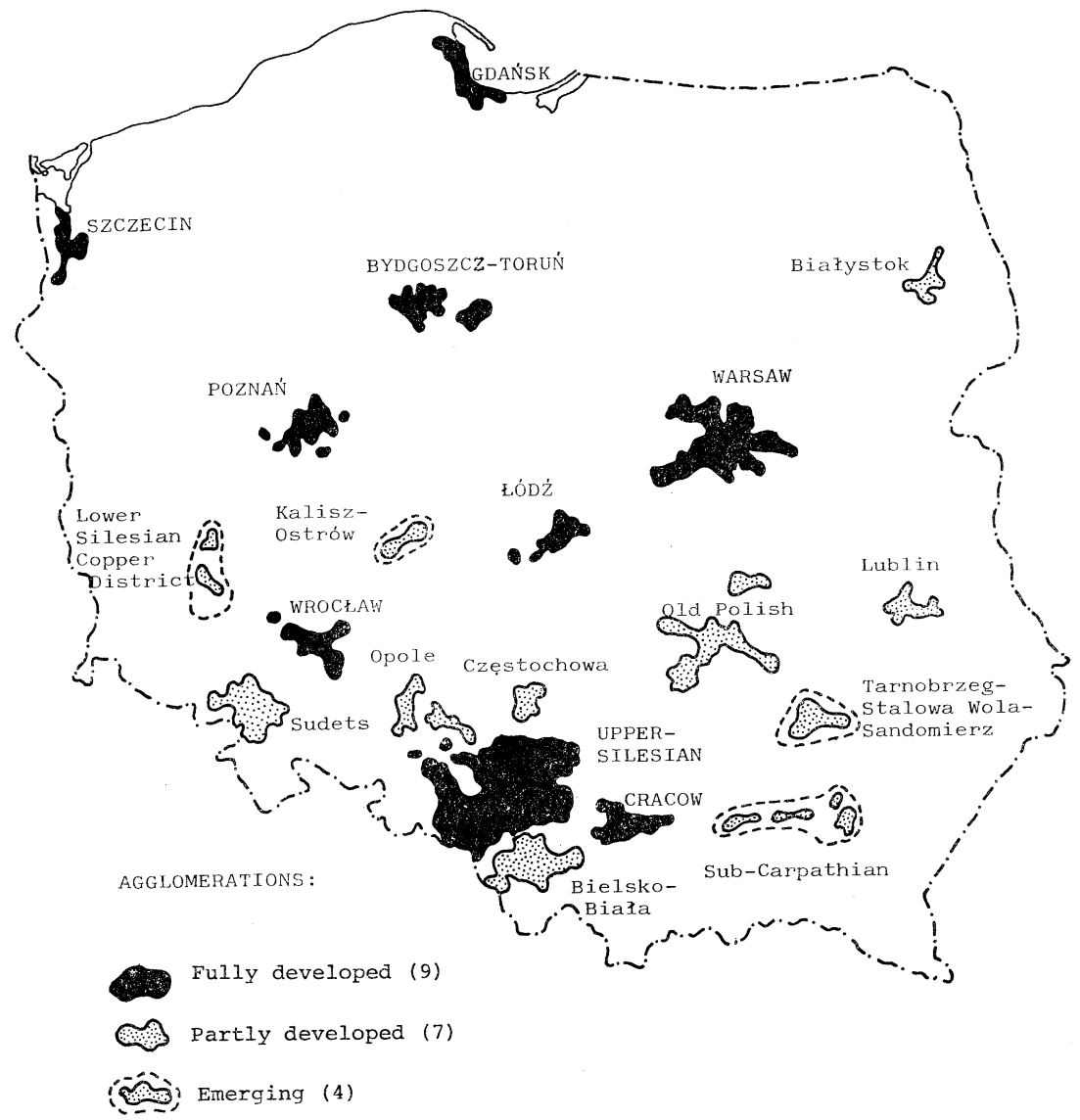

Figure 5. Polish urban agglomerations $(1980 \sim 1990)$

and 18.3 per thousand in the rural areas in 1951). After 1956 the natural increase in the urban areas decreased and at present (1980) it reached a level of 9.2 per thousand (in the rural areas 10.3 per thousand). The new phenomena observed in the natural increase of Polish urban settlements is a steady growth from 7.0 at the beginning of 1970 to 9.2 per thousand in 1980 . On the other hand, rural areas are in stagnation (10.2 per thousand in 1970 and 10.3 per thousand in 1980).

Rapid aging of the population and changes in the occupational structure have been noted due to the intensive post-war development of the national economy and the urbanization processes. In 1980 the proportion of people aged 60 years and older numbered $11.8 \%$ of the total urban population. In the rural areas this ratio was higher : $15.3 \%$ of the total rural population (the national average was 13.2\%). The lower percentage of elderly people in the total urban population is mainly due to the steady influx of young migrants from the rural areas. Since young people constitute the majority of migrants to the urban areas (more than $50 \%$ of them being $18 \sim 34$ years old), internal migrations are one of the main factors of the relative youth of the Polish urban agglomeration.

Before the Second World War only $40 \%$ of the total population made their living in non-agricultural jobs. In 1950 the non-agricultural population constituted about 53\% of the country's population, in $196062 \%$ 

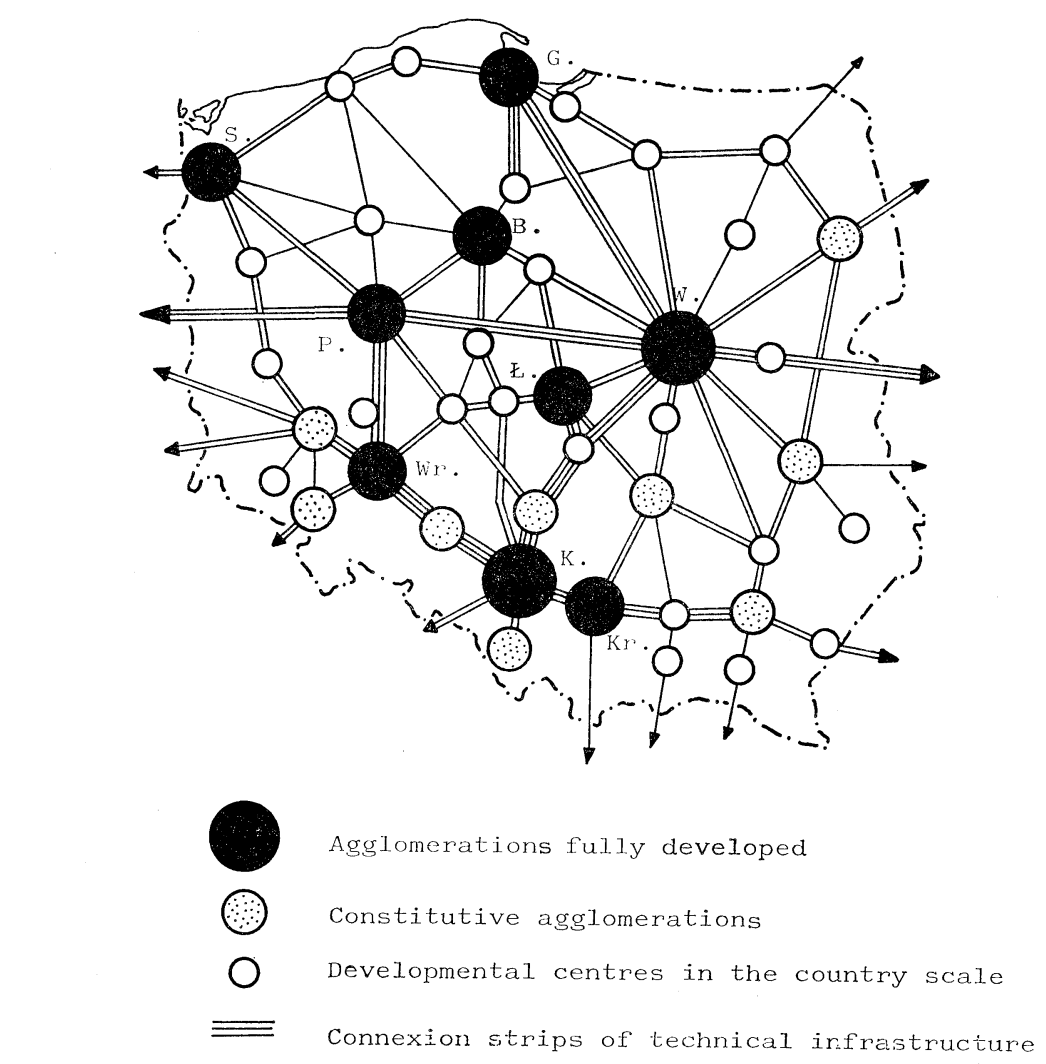

W-Warsaw; K-Katowice; Kr-Kraków; G-Gdańsk; S-Szczecin; B-Bydgoszcz; Ł-Łódź; P-Foznań; Wr-Wrocław

Figure 6. Polycentrical model of spatial structure of Poland (after S. Berezowski, 1977)

and in 1980 this index reached about $75 \%$. At present, more than $95 \%$ of the urban population have non-agricultural occupations, but in towns in Eastern Poland, the agricultural population constitute nearly half of the total population (this region is characterized by the predominance of small urban settlements with populations of less than 20,000 inhabitants, see Fig. 4).

Actually, as a consequence of the country's economic situation the tempo of the urbanization processes has been declining. For instance, in state and cooperative housing constructions, which occupy more than $95 \%$ of dwelling houses in the territory of Polish cities, there has been a sharp decrease in the construction of new flats from 1970 to 1980 and this decrease represented approximately
$25 \%$.

What will be the future for Polish urbanization? One of the answers to this question contains the polycentric model of the spatial structure of the country. In this concept the distinguished 16 (fully and partly developed) urban agglomerations will perform functions of the main economic knots in the frame of the polycentric settlement system(Fig. 6).

The areas closed in by the arterial roads and main settlement links will be utilized for farming purposes and recreation. By the end of the 20th century, it is estimated that the urban population will reach 65 $75 \%$ of the total population. The urban agglomerations will contain almost 23 million inhabitants who will account for about $80 \%$ of the urban population of the country. 


\section{References}

Dziewoński, K., Kosiński, L. (1964): Development and Distribution of Population in Poland in 20th Century. Geogr. Rev., No. 37, Warsaw.

Dziewoński, K. (1975): The Place of Urban Ag. glomerations in the Settlement System of Poland.
Geographia Polonica, No. 30, Warsaw.

Dziewoński, K., Malisz, B. (1978): Evolution of Spatial-Economic Structure of Country. Studies of KPZK PAN, t. LXII, PWN, Warsaw.

Regulski, J. (1980): Development of Cities in Poland. PWN, Warsaw.

Statistical Yearbook (1981): GUS, Warsaw.

\section{ポーランドにおける都市化の若干の局面}

\section{ライムンド S. ミデール*}

第 2 次大戦後のポーランド経済, とくに工業の急 激な発展によって, 急速な都市化過程が生じた。 1950 80年つ間に，都市人口割合は総人口の $38.4 \%$ から $58.7 \%$ へ増大した。 この時期に，ポーランドの 市・町の人口は 1,140 万人 (54.3\%) 増加した. その うち, ちょうど $42.4 \%$ は自然増加, $33.9 \%$ は農村地 域からの流入， $23.7 \%$ は行政区域の変更によるもの である.

1980年末には，ポーランドには 804 の都市と都市 的集落とがあった，ポーランドの町のうちでは，小 さい集落(人口 1 万人以下)が圧倒的に多い，それら の小集落は, 都市的集落総数のうち $55.9 \%$ を占め, 同時に全都市人口の約 $10 \%$ を占めている. 同年，人 口 5 万人以上の町は 75 (都市的集落総数の $9.3 \%$ )を 数え，全都市人口の $62 \%$ 以上占めている.

空間的視点から見て, 最も都市化しているのはポ ーランド西部抢よび南央部であり, 全国の都市化指 数を超えている. 国土には16の都市アグロメレーシ ョンがつくり出され, その中で 9 つが充分に発達し
たもの(上シロンスク，ワルシャワ，ウッジ，クラク フ, ブロツラフ, ポズナニ, シュチェチン, グタニ スク・グジニア, ビドゴシュチ・トルニ)であり, 7 つがある程度発達した都市アグロメレーションであ る(スデーティ, スタロ・ポルスカ, ビエルスコ, オ ポーレ, チェンストホバ, ルブリン, ビアウイスト ック). 顕著な16の都市アグロメレーションは，全 国人口の $20 \%$ 以，都市人口の $60 \%$ 以上，全産業人 口の約 $65 \%$ 以上占めている. 別に，4つの都市ア グロメレーションの発生が目立つ。すなわち, タル ノブジェックーースタロバ・ボラ一ーサンドミエシ, 周カルパチア, 下シロンスク, カリシュ・オストル フである. 20 世紀末には, ポーランドの総人口は, 3, 900 4, 000万人の水準に達し，そのうち65 75\% は都市人口と推定される. 現在目立つ16の都市アグ ロメレーションは, 多中心地結合集落システムの内 部で主要な経済的中心地の機能を果たし, ポーラン ドの都市人口の約 $80 \% か ゙$ 集まっているであろう. 